\title{
Comparison of Pain Scores During Retrieval of Ureteral Stents Using Rigid Cystoscope Versus Rigid Ureteroscope in an Office Setting: A Prospective Study
}

\author{
Bir Ofis Ortamında Rijit Sistoskop ile Rijit Üreteroskop Kullanılarak Üreteral Stentlerin \\ Alınması Sırasında Ağrı Skorlarının Karşılaştıııması: Prospektif Bir Çalışma
}

(D) Siddalingeshwar I Neeli1, (D) Sree Harsha Nutalpati2

1 Jawaharlal Nehru Medical College and KLES Dr Prabhakar Kore Hospital and MRC, Department of Urology, Belagavi, India

2Jawaharlal Nehru Medical College and KLES Dr Prabhakar Kore Hospital and MRC, Department of Urology, Belagavi, India

\section{What's known on the subject? and What does the study add?}

Many patients, especially males, complain of severe pain and discomfort during stent removal using rigid cystoscope in office setting which can largely be attributed to the longer length of urethra, enlarged prostate and bigger calibre of rigid cystoscope. We employed reduction in the caliber of the retrieving instrument by using rigid ureteroscope which is easily available in every urologist's armamentarium. Though a couple of studies have employed rigid ureteroscope for stent retrieval, no study has studied male patients exclusively. Our study compares stent retrieval with rigid cystoscope and rigid ureteroscope in office setting making it an affordable and dependable method.

\begin{abstract}
Objective: Ureteral stents inserted to prevent obstruction to the flow of urine need to be removed after they serve the purpose of their insertion. The most commonly practiced method for stent removal is using a rigid cystoscope in an office setting. However, it is quite painful and may require general anesthesia especially in males. Due to their small caliber, rigid ureteroscope can reduce patient discomfort during ureteral stent retrieval procedure. In this study, we compared the pain scores during ureteral stent retrieval using a rigid cystoscope and a rigid ureteroscope.

Materials and Methods: A prospective study was conducted with 64 male patients with ureteral stents who were divided into two groups. Group A had 36 patients who underwent stent retrieval with rigid cystoscope while group B had 28 patients who underwent with rigid ureteroscope. Pain experienced during the procedure and during the first void thereafter were recorded using visual analog scale.

Results: The patients who underwent stent retrieval using rigid cystoscope (mean $7.05 \pm 1.21$ ) had a significantly higher $(p<0.0001)$ pain score compared to those who underwent it using rigid ureteroscope (mean 2.57 \pm 1.04 ). The pain scores during the first void after the procedure as reported by patients in groups $A$ and $B$ were $6.58 \pm 1.27$ and $3.03 \pm 0.96(p<0.0001)$, respectively.

Conclusion: Rigid ureteroscopic stent retrieval is a less painful, safe, and dependable method, with a reduced requirement for postoperative analgesics as compared to rigid cystoscopic stent retrieval.
\end{abstract}

Keywords: Rigid cystoscope, Rigid ureteroscope, Ureteral stents, Stent retrieval

Öz

Amaç: İdrar akışının tıkanmasını önlemek için yerleştirilen üreteral stentler, yerleştirilme amacına hizmet ettikten sonra çıkarılmalıdır. Stentin çıkarılması için en sık uygulanan yöntem, muayenehane koşullarında rijit bir sistoskop kullanmaktır. Bununla birlikte, oldukça ağrılıdır ve özellikle erkeklerde genel anestezi gerektirebilir. Küçük kalibreleri nedeniyle, rijit üreteroskop, üreter stent ekstraksiyon prosedürü sırasında hastanın rahatsızlığını azaltabilir. Bu çalışmada, rijit bir sistoskop ve rijit bir üreteroskop kullanarak yapılan üreter stent ekstraksiyonu sırasındaki ağrı skorlarını karşılaştırdık.

Gereç ve Yöntem: Üreteral stentli 64 erkek hasta iki gruba ayrılarak prospektif olarak değerlendirildi. Grup A, rijit sistoskop ile stent ekstraksiyonu yapılan 36 hasta; grup B ise rijit üreteroskop ile stent ekstraksiyonu yapılan 28 hastadan oluşmakta idi. İşlem sırasında ve sonrasındaki ilk idrar çıkışı sırasında yaşanan ağrı görsel analog skala kullanılarak kaydedildi.

Correspondence: Siddalingeshwar I Neeli M.Ch, Jawaharlal Nehru Medical College and KLES Dr Prabhakar Kore Hospital and MRC, Department of Urology, Belagavi, India Phone: +91 8412473777 E-mail: sineeli@gmail.com ORCID-ID: orcid.org/0000-0001-6565-1443

Received: $19.01 .2020 \quad$ Accepted: 15.02 .2020

Cite this article as: Neeli SI, Nutalpati SH. Comparison of Pain Scores During Retrieval of Ureteral Stents Using Rigid Cystoscope Versus Rigid Ureteroscope in an Office Setting: A Prospective Study. J Urol Surg 2020;7(3):172-176.

๑Copyright 2020 by the Association of Urological Surgery / Journal of Urological Surgery published by Galenos Publishing House. 
Bulgular: Rijit sistoskop kullanılarak stent ekstraksiyonu yapılan hastalar (ortalama 7,05 $\pm 1,21$ ), rijit üreteroskop kullanılarak stent ekstraksiyonu yapılanlara göre anlamlı olarak daha yüksek $(p<0,0001)$ ağrı skoruna sahipti (ortalama $2,57 \pm 1,04)$. A ve B gruplarındaki hastalar tarafından bildirilen

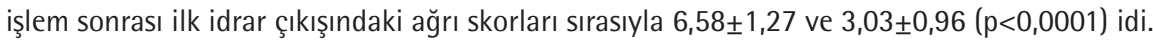

Sonuç: Rijit üreteroskopik stent ekstraksiyonu, rijit sistoskopik stent ekstraksiyonuna kıyasla postoperatif analjeziklere daha az ihtiyaç duyulan, daha az ağrılı, güvenli ve güvenilir bir yöntemdir.

Anahtar Kelimeler: Rijit sistoskop, Rijit üreteroskop, Üreteral stentler, Stent çıkarımı

\section{Introduction}

Ureteral Double-J stents are the most commonly used device in urological practice and are primarily used to maintain the patency of the ureter. Ureteral stents are used to relieve obstruction, which can occur due to various intrinsic and extrinsic etiologies during treatment of ureteric injuries and after ureteral anastomosis (1). Prophylactic ureteral stenting may also be done prior to extracorporeal shock wave lithotripsy and pelvic surgeries (1). Ureteral stent placement is associated to some degree of morbidity in the majority of patients in the form of generalized urinary discomfort, urinary tract infection and encrustation (2-4). The stents need to be removed after the purpose of their placement is served.

The most commonly practiced method for stent removal in an office setting is by the use of a rigid cystoscope (5). Many patients especially males complain of severe pain and discomfort during such procedure, which can largely be attributed to the longer length of urethra in males, enlarged prostate and bigger caliber of rigid cystoscope (6). Various methods like administering of general anesthesia, use of periprocedural analgesics and use of flexible cystoscope have been suggested to reduce the pain and discomfort associated during stent retrieval (6-8). Modifications in the stent design such as magnetic stents and biodegradable stents have been employed to obviate the need for endoscope for stent removal; however their use has not been widely accepted $(9,10)$. Another suggested method is to reduce the caliber of the cystoscope to reduce the pain. One such scope is a rigid ureteroscope, which is present in the armamentarium of all urologists. We conducted a prospective study to compare the post-procedural pain scores using a visual analog scale (VAS), after ureteral stent retrieval in male patients using rigid cystoscope and a rigid ureteroscope.

\section{Materials and Methods}

\section{Patient Cohort}

This prospective study was conducted from January to June 2018 after approval from the Institutional Ethics Committee (MDC/ DOME/498 dated 11-23-2017) of JNMC Institutional Ethics Committee on Human Subjects Research, J. N. Medical College, Belagavi). The patients with residual stones, active urinary infection, history of sepsis, renal failure, bilateral ureteral stents, and migrated stents were not eligible for the study. A total of 82 adult male patients, with unilateral Double-J uretral stents, were assessed for eligibility for the study and 64 patients were enrolled for randomization (Figure 1).

All patients were assessed by the kidney, ureter, and bladder radiograph prior to the procedure.

Using random number table method, patients were divided into two groups, which were based on the method of stent retrieval. Group A comprising 36 patients who had their stents retrieved using a 17 Fr rigid cystoscope (Karl Storz, Tuttlingen, Germany) with grasping forceps. Group B consisted of 28 patients who had their stent retrieved using an 8.0/9.8 Fr rigid ureteroscope (Richard Wolf, Knittlingen, Germany) and grasping forceps.

\section{Procedure and Data Collection}

The stent retrieval procedures were performed by a single urologist to minimize the errors or biases. A written consent was obtained from all the participants after explaining the procedure in their vernacular language. A single dose of second-generation cephalosporin antibiotic was administered intravenously before the procedure. The stents were retrieved after putting the patients in lithotomy position and instilling $15 \mathrm{~mL}$ of $2 \%$ lignocaine jelly into the urethra. The stent was retrieved with grasping forceps using rigid cystoscope in the patients randomized to group $A$ and rigid ureteroscope in the patients randomized to group B. The duration of stent placement, laterality of stent, indication for stent placement, postprocedure pain score, and pain during first void, after the procedure were assessed in each patient. The VAS was used by each patient at the end of the procedure to mark his subjective perception of pain during the procedure and during the first void after the procedure. Other urinary complains such as hematuria, frequency, and urgency as reported by the patients were documented. All the patients were discharged home within $1 \mathrm{~h}$ of postprocedural voiding.

\section{Statistical Analysis}

A sample size of 62 patients was calculated using comparing two proportion formulas. It was estimated to yield $80 \%$ power (type II or beta error of $0.20 \%$ ) to detect a difference of $15 \%$ or more between two groups, allowing 5\% of type I error. Totally, 64 patients were enrolled in the study. Statistical analysis was done using SPSS Software Version 20. Univariable analysis was 


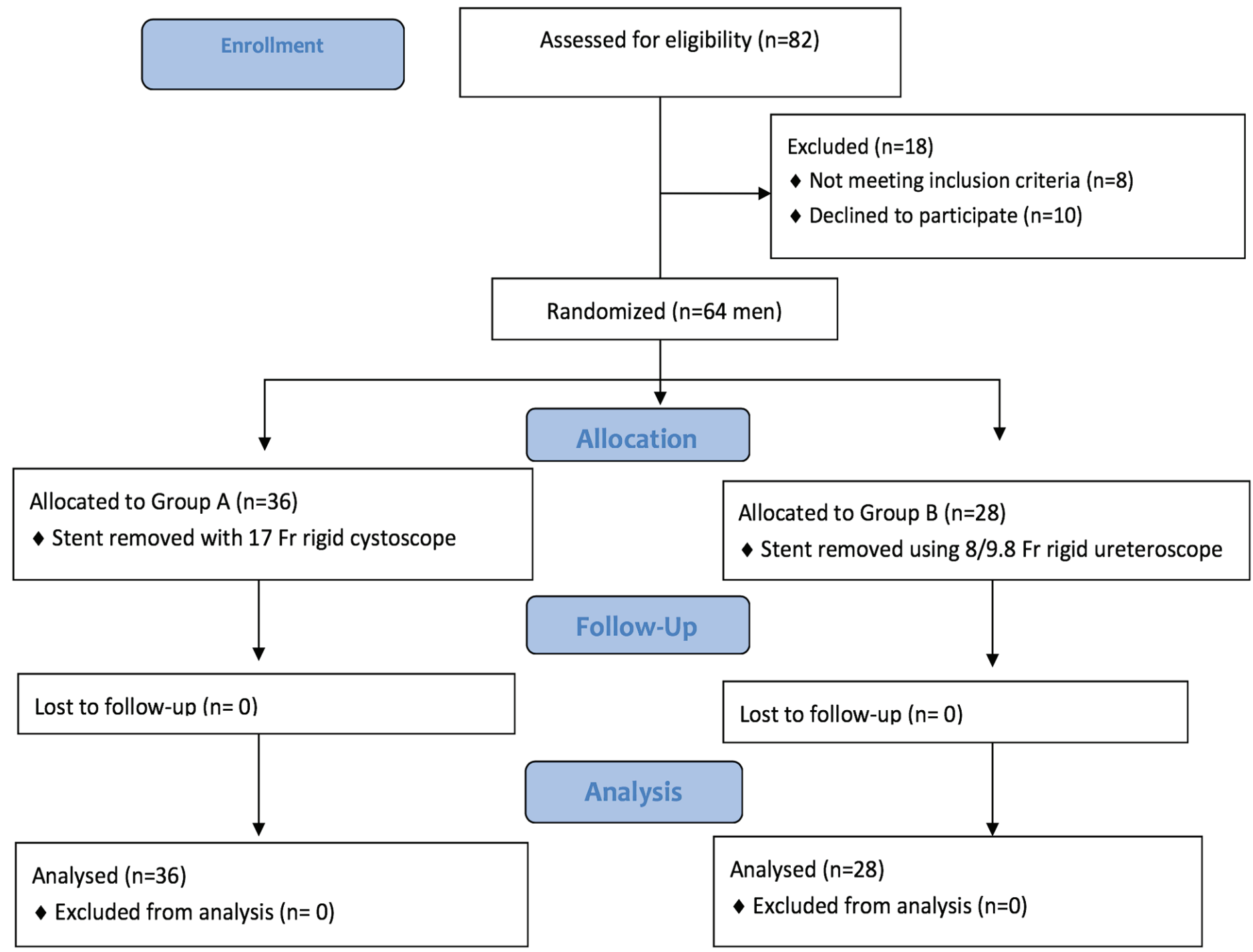

Figure 1. CONSORT statement

performed using Pearson $\chi^{2}$ statistics and Fischer's Exact test for categorical data. $P$ values $<0.05$ were considered significant.

\section{Results}

The two groups were compared with regards to age, laterality of stent, indications for stent placement, and duration of the stent (Table 1). The highest indication for stent placement in our study was ureteroscopic lithotripsy (59.37\%) followed by percutaneous nephrolithotomy cases (20.31\%). The mean duration of stent placement in group A and B was $22.69 \pm 17.13$ and $25.01 \pm 16.87$ days, respectively. Stent-related symptoms (hematuria, frequency, urgency, and dysuria) were reported in 31 patients $(48.43 \%)$. All the ureteral stents were successfully retrieved, using either of the scopes, in both groups.

The reported mean VAS pain score during the stent retrieval using rigid cystoscope was significantly higher than that of rigid ureteroscope (Table 2). Also the pain experienced during the first void after the procedure was higher in group A. Of the total number of patients, seven (10.93\%) required analgesia after stent retrieval, six of whom belonged to group $A_{\text {, having }}$ postprocedure VAS pain score more than 7. In five cases, oral paracetamol $650 \mathrm{mg}$ and the two other cases injectable analgesic medications were administered to the patients. In each group, one of the patient reported mild hematuria during the first void after the procedure. Two patients in group $A$ and one patient in group B complained of urgency and frequency after the procedure. None of the patients were reported suffering from 


\begin{tabular}{|l|l|l|}
\hline \multicolumn{2}{|l|}{ Table 1. Patient characteristics } \\
\hline Variables & $\begin{array}{l}\text { Rigid } \\
\text { cystoscope }\end{array}$ & $\begin{array}{l}\text { Rigid } \\
\text { ureteroscope }\end{array}$ \\
\hline No. of cases & 36 & 28 \\
\hline Mean age \pm SD & $43.9 \pm 13.3$ & $39.21 \pm 15.3$ \\
\hline Laterality (right / left) & $14 / 22$ & $16 / 12$ \\
\hline Duration of stent (mean \pm SD) & $22.69 \pm 17.13$ & $25.01 \pm 16.87$ \\
\hline $\begin{array}{l}\text { Bothersome stent-related } \\
\text { symptoms }\end{array}$ & 17 & 14 \\
\hline Indications for stenting & \multicolumn{2}{|l|}{} \\
\hline Ureteroscopy & 24 & 14 \\
\hline PCNL & 07 & 06 \\
\hline ESWL & 02 & 04 \\
\hline Obstructive uropathy & 02 & 01 \\
\hline Pyeloplasty & 01 & 03 \\
\hline $\begin{array}{l}\text { Analgesic requirement } \\
\text { postprocedure }\end{array}$ & 06 & 01 \\
\hline $\begin{array}{l}\text { PCNL: Percutaneous nephrolithonom, ESWL: Ekstra corporeal shock wave lithotripsy, } \\
\text { SD: Stardard deviation }\end{array}$ & \multicolumn{2}{|l}{} \\
\hline
\end{tabular}

Table 2. Postprocedure visual analog scale pain score in two groups

\begin{tabular}{|l|l|l|l|}
\hline Variables & $\begin{array}{l}\text { Rigid } \\
\text { cystoscope }\end{array}$ & $\begin{array}{l}\text { Rigid } \\
\text { ureteroscope }\end{array}$ & p value \\
\hline VAS pain score (mean \pm SD) & $7.05 \pm 1.21$ & $2.57 \pm 1.04$ & $<0.0001$ \\
\hline $\begin{array}{l}\text { Pain during first void } \\
\text { postprocedure (mean } \pm \text { SD) }\end{array}$ & $6.58 \pm 1.27$ & $3.03 \pm 0.96$ & $<0.0001$ \\
\hline \multicolumn{2}{|l|}{ VAS: visual analog scale, SD: Stardard deviation } & \\
\hline
\end{tabular}

fever or retention of urine after stent removal.

\section{Discussion}

Stent placement and subsequent removal results in higher procedural costs than when it is not used. In an uncomplicated ureteroscopy (URS) placement of a stent do not have any advantage and in fact may add to the morbidity $(11,12)$. However, majority of urologists place a stent after uncomplicated URS in the hope of reducing the visits to the emergency department by such unstented patients (13).

Newer stents incorporate extraction strings made of fine suture material secured to the distal end of the stent, which is visible at the urethral meatus.

The extraction strings avoid the need to repeat cystoscopy for stent removal. However, most of the urologists remove stent extraction strings prior to their insertion due to the concerns over perceived risks, such as increased LUTS from string irritation, stent dislodgement, infection, stent retention due to patients forgetting to remove stents, broken strings, and lack of strong evidence relating to its safety and tolerability (14).
In developed countries, flexible cystoscope is used to retrieve ureteral stents in office setting $(1,15)$. Since flexible cystoscopes are expensive and less readily available in developing countries, rigid cystoscopes are routinely employed for removal of ureteral stents in office setting (8).

Owing to the larger caliber of rigid cystoscope, which can induce pain while insertion and during the procedure, several other factors make this method more difficult, especially in male patients, including longer urethra and prostatic enlargement (6). Söylemez et al. (15) described the use of rigid ureteroscope to retrieve ureteral stents as an alternative that may be less painful as compared to rigid cystoscope.

We have been routinely using rigid cystoscopic and ureteroscopic method for retrieval of ureteral stents in our center. In this study, we found out that post-procedural VAS pain scores for patients whose ureteral stents were retrieved using rigid ureteroscope $(2.57 \pm 1.04)$ were less as compared to rigid cystoscopy group $(7.05 \pm 1.21 ; p<0.0001)$.

Patients also reported pain on VAS during first void postprocedure in our study, which were $6.58 \pm 1.27$ in cystoscope group versus $3.03 \pm 0.96$ in ureteroscope group $(p<0001)$. Söylemez et al. (15) also reported that the mean operative pain scores were significantly higher in patients undergoing stent retrieval using rigid cystoscope than rigid ureteroscope group $(p<0.01)$.

Kim et al. (6) conducted a study on rigid cystoscopic ureteral stent retrieval using analgesics [Intravenous (IV) ketorolac, midazolam] and sedation (IV propofol) to assess procedural pain and postprocedure satisfaction of patients. VAS pain score of 8 for IV ketorolac group, score of 5 for midazolam group and no procedural pain in propofol group noted. Use of midazolam and propofol needs observation in the postprocedure period, especially in patients with comorbid illnesses, which also adds to cost of overall hospital visit.

Single dose of Rofecoxib, a non-steroidal anti-inflammatory drug (NSAID) was studied in a prospective, double-blind, placebo-controlled trial by Tadros et al. (16) in 22 patients undergoing cystoscopic stent retrieval. The authors concluded that in placebo group, postoperative VAS score $\geq 7$ (severe pain) was found in 55\% of the patient and required postprocedure narcotic analgesics, whereas a single dose of Rofecoxib prevented severe pain in NSAID arm during post- operative procedure. Oral NSAID (Diclofenac) use was also evaluated by Karthikeyan et al. (8) in a double-blind, placebo-controlled trial in 121 patients undergoing ureteral stent retrieval using cystoscope. VAS pain score during procedure, at first void, and $24 \mathrm{~h}$ postop was assessed, and authors concluded that use of oral diclofenac significantly reduced pain with minimal side effects (8). 
In a study by Söylemez et al. (15), the mean pain scores, irritative voiding symptom scores and hematuria were not statistically significant in patients undergoing stent retrieval using flexible cystoscope and rigid ureteroscope. They concluded that stent retrieval using rigid ureteroscopy is safe, cost effective, and widely usable method (17).

It is evident from this current study that the postprocedure VAS pain scores and discomfort were significantly less along with less discomfort using a smaller caliber scope for stent retrieval. Only one patient in the rigid ureteroscopy group required postoperative analgesia as compared to six patients in the rigid cystoscopy group.

\section{Study Limitations}

The limitations of our study include the relatively small sample size and a single-center study, which will have an unavoidable inherent bias. It would be more ideal to conduct a prospective study with a larger sample size in a multi-center setup. Also, we have not assessed the cost effectiveness in either group.

However, it is safe to conclude that use of smaller caliber scope for stent retrieval can be a viable and less painful alternative to conventional rigid cystoscopic stent retrieval.

\section{Conclusion}

In the present study, use of the ureteroscope method for ureteral stent retrieval was less painful, safe, effective, and dependable method. Other advantages include wider availability, cost effective, and proficiency of urologists with its use. This helps in reducing the procedural discomfort and the use of postoperative analgesics among the patients.

\section{Ethics}

Ethics Committee Approval: This prospective study was conducted from January to June 2018 after approval from the Institutional Ethics Committee (MDC/ DOME/498 dated 1123-2017) of JNMC Institutional Ethics Committee on Human Subjects Research, J. N. Medical College, Belagavi).

Informed Consent: Taken in the vernacular language spoken by the patient (Kannada, Marathi and Hindi).

Peer-review: Externally and internally peer-reviewed.

\section{Authorship Contributions}

Surgical and Medical Practices: S.I.N, S.H.N., Concept: S.I.N, S.H.N., Design: S.I.N, S.H.N., Data Collection or Processing: S.I.N, S.H.N., Analysis or Interpretation: S.I.N, S.H.N., Literature Search: S.I.N, S.H.N., Writing: S.I.N, S.H.N.

Conflict of Interest: No conflict of interest was declared by the authors.
Financial Disclosure: The authors declared that this study received no financial support.

\section{References}

1. Beysens M, Tailly TO. Ureteral stents in urolithiasis. J Urol 2018;5:274-286.

2. Zumstein $\mathrm{V}$, Betschart $\mathrm{P}$, Albrich WC, Buhmann MT, Ren $\mathrm{Q}$, Schmid HP, Abt D. Biofilm formation on ureteral stents - incidence, clinical impact, and prevention. Swiss Med Wkly 2017;147:14408.

3. El-Faqih SR, Shamsuddin AB, Chakrabarti A, Atassi R, Kardar AH, Osman MK, Husain I. Polyurethane internal ureteral stents in treatment of stone patients: morbidity related to indwelling times. J Urol 1991;146:e1487-e1491.

4. Kawahara $T$, Ito $H$, Terao $H$, Yoshida $M$, Matsuzaki J. Ureteral stent encrustation, incrustation, and coloring: morbidity related to indwelling times. J Endourol 2012;26:e178-e82.

5. Fro"hlich $M$, Fehr J, Sulser T, Eberli D, Mortezavi A. Extraction strings for ureteric stents: is there an increased risk for urinary tract infections? Surg Infect (Larchmt) 2017;18:e936-e40.

6. Kim JH, Park SY, Kim MG, Choi H, Song D, Cho SW, Song YS. Pain and satisfaction during rigid cystoscopic ureteral stent removal: a preliminary study. BMC Urol 2014;14:90.

7. Loh-Doyle JC, Low RK, Monga M, Nguyen MM. Patient experiences and preferences with ureteral stent removal. J Endourol 2015;29:e35-e40.

8. Karthikeyan VS, Keshavamurthy R, Mallya A, Chikka Moga Siddaiah M, Kumar $S$, Chandrashekar CR. Efficacy of preprocedural diclofenac in men undergoing double J stent removal under local anesthesia: A double-blind, randomized control trial. Indian J Urol 2017:33:53-57.

9. Rassweiler,MC, Michel MS, Ritter M, Honeck P. Magnetic Ureteral Stent Removal Without Cystoscopy: A Randomized Controlled Trial. J Endourol 2017;31:762-766.

10. Barros AA, Rita A, Duarte $C$, Pires RA, Sampaio-Marques $B$, Ludovico $P$, Lima $E$, Mano JF, Reis RL. Bioresorbable ureteral stents from natural origin polymers. J Biomed Mater Res B Appl Biomater 2015;103:608-617.

11. Byrne RR, Auge BK, Kourambas J, Munver R, Delvecchio F, Preminger GM. Routine ureteral stenting is not necessary after ureteroscopy and ureterpyeloscopy: a randomized trial. J Endourol 2002;16:9-13.

12. Chen YT, Chen J, Wong WY, Yang SS, Hsieh $\mathrm{CH}$, Wang CC. Is ureteral stenting necessary after uncomplicated ureteroscopic lithotripsy? A prospective randomized controlled trial. J Urol 2002;167:1977-1980.

13. Makarov DV, Trock BJ, Allaf ME, Matlaga BR. The effect of ureteral stent placement on post-ureteroscopy complications: a meta-analysis. Urology 2008;71:796-800.

14. Oliver R, Wells $H_{\text {, Traxer }}$, Knoll $T$, Aboumarzouk 0 , Biyani CS, Somani BK YAU Group. Ureteric stents on extraction strings: A systematic review of literature. Urolithiasis 2018;46:129-136.

15. Söylemez H, Altunoluk B, Onem K, Oguz F. Minimally painful retrieval of ureteral stents using by ureteroscope. J Clin Exp Invest 2010;1:e7-e11.

16. Tadros NN, Bland L, Legg E, Olyaei A, Conlin MJ. A single dose of a nonsteroidal anti- inflammatory drug (NSAID) prevents severe pain after ureteric stent removal: a prospective, randomized, double-blind, placebocontrolled trial. BJU Int 2012;11:101-105.

17. Söylemez H, Sancaktutar AA, Bozkurt Y, Atar M, Penbegül N, Yildirim K. A Cheap Minimally Painful and Widely Usable Alternative for Retrieving Ureteral Stents. Urol Int 2011;87:199-204. 